\title{
4 Kulturnation: The Black Women's Renaissance, Folk Heritage and the Essential Black Female Matrix
}

\subsection{Discursive Practice of Heritage and Nation-building}

Heritage is a key concept in any discussion of nationhood. As Yuval-Davis has argued, "the symbolic heritage provided by language and/or religion and/or other customs and traditions is constructed as the 'essence' of 'the nation' (Kulturnation)" (Gender and Nation 21). The confluence of heritage and nation has been well documented by Lowenthal (The Heritage Crusade and the Spoils of History 1998), Winter (Post-Conflict Heritage, Postcolonial Tourism: Culture, Politics and Development at Angkor 2007), Anheier and Isar (Heritage, Memory and Identity 2011), Watson (2013), and Stuart Hall, who argued in "Whose Heritage? Un-settling the Heritage, Re-imaging the PostNation” (2005), that:

\footnotetext{
[w]e should think of The Heritage as a discursive practice. It is one of the ways in which the nation slowly constructs for itself a sort of collective social memory. Just as individuals and families construct their identities by "storying" the various random incidents and contingent turning points of their lives into a single, coherent, narrative, so nations construct identities by selectively binding their chosen high points and memorable achievements into an unfolding "national story." This story is what is called "Tradition." (23)
}

To understand heritage as a discursive practice is to treat it as a process whereby present-day collective identities are created (Hall, “Whose Heritage?”; Harvey, "Heritage Pasts and Heritage Presents”; L. Smith, Uses of Heritage). National/ethnic identities are quintessential forms of cultural narratives (Yuval-Davis 43), whose construction depends on "the insertion of the present into the miasma of tradition" (Higson, English Heritage 50).

This understanding of heritage is relatively new. It came into being in the 1980s, when the BWR also reached its apogee, under the influence of poststructuralism. At that time, heritage scholarship was transformed from what Rodney Harrison (borrowing from Arjun Appadurai) labelled a "predatory" way of thinking about heritage (Heritage 22), into "a post-post-structural, or more-than-representational, labyrinth of individuated, affective, experiential and embodied themes" (Waterton and Watson, The Palgrave Handbook 1). The predatory way of thinking assumed that "management of particular cultural heritage ... require[s] the elimination or removal of other memories or forms of recollection" (Harrison, Heritage 22). It also laments that "[h] eritage is what we inherit and what we must hold dear" (Gnecco, "Heritage" 265); and "a physical thing left over from the past" (Moody, "Heritage” 113). Conversely, the "post-poststructural" way of thinking proposed that heritage is "an actively constructed understanding, a discourse about the past which is ever in fluctuation" (ibid.). This paradigm shift deprived heritage of its "quasi-mystical condition" and the "sym- 
bolic centrality that everyone has to recognize and revere" (Gnecco, "Heritage” 263). Instead, research was re-focused onto critical analysis that highlighted how heritage discourse "order[s] its representations around hegemonic socio-cultural themes, including national identity, social cohesion and the power-relational values of dominant groups" (Waterton and Watson, The Palgrave Handbook 9). In other words, in the 1980s, scholars started to concern themselves with the question of how meaning is constructed in heritage narratives. As a result of this shift in critical attention, "heritage was revealed to be a selective process, thereby prompting a focus upon issues of power, identity and control" (ibid. 6). ${ }^{47}$

Smith's Uses of Heritage has played a pivotal role in the development of this critique, which debunked myths about the inherent value of heritage, and revealed it as a subjective ideological discourse and a cultural process or performance that is not so much about the past as about the present. Other studies, such as those by Harvey ("Heritage Pasts and Heritage Presents" 2001); Byrne ("Heritage as Social Action" 2008); Smith and Waterton, (Heritage, Communities and Archaeology 2009); and Harrison (Heritage: Critical Approaches 2013), emphasized the "dissonant" nature of heritage "whereby constructions of the past are valorized, negotiated or contested, and instrumentalized in the present for future goals" (Giblin, "Critical Approaches" 317). This dissonance is not only the result of negotiation within one tradition or nation; it can also be the effect of tensions between different and competing heritage discourses. For example, the dominant “'authorized heritage discourse' [the so-called AHD], undergirded by dynamics of inclusion and exclusion [and] policed by institutional heritage discourses" can clash with other - minority, indigenous or diasporic - heritage discourses that contest and destabilize it at the grassroots level ("Heritage" 273).

Unfortunately, these subversive discourses, which "[position] alternative conceptions of time, past, ancestors and life" (Gnecco 263), often duplicate the essentialism of the dominant (postmodern, Euro-American) culture, whilst retaining their own brand of vernacular essentialism. The geographer David Lowenthal reminds us that "[f]olk models," in particular, "cast heritage as traditional, unchanging cultural practices that have been handed down since time immemorial” (The Past Is a Foreign Country 10). Similarly, Reed states that they evoke a nostalgia for the rural past "a simpler, better time" ("Of Routes and Roots" 382). Folk heritage, which relates to myths of common origin that may or may not be historically valid, and to myths of common destiny (Yuval-Davis, Gender and Nation 43), projects a conservative view

47 Another definition of heritage sees it as "a version of the past received through objects and display, representations and engagements, spectacular locations and events, memories and commemorations, and the preparation of places for cultural purposes and consumption" (Waterton and Watson, The Palgrave Handbook 1). This definition has not lost its relevance: it suggests, that "heritage" is a very broad term that finds usage in many different disciplines and contexts, and can be "a form of inauthentic history displayed in space"; or else it can designate "a process of tourism expansion and postmodern patterns of consumption" (Nuala C. Johnson, "Heritage and Geography” 163). 
of history and tradition. Meskell suggests that its "intense political heritage rhetoric" often seeks to compensate for a "negative heritage" of marginalization, dispossession and discrimination with by recourse to a romanticized and idealized rural past ("Negative Heritage" 557). Folk heritage usually privileges memory and orality because, as Gilroy has observed, memory work can act as a form of counter-history, disrupting, complicating and contesting dominant racialized (and, I would add, gendered) cultural politics.

\section{2 "The Black Middle-class Hoopla": Heritage, Cultural Nationalism and Class}

BWR fiction of the 1980s surged to prominence on the wave of a memory boom, which, as Jesús Martín-Barbero has claimed, could be seen as a heritage boom (Gnecco, "Heritage" 270). It was a highly politicized discursive practice that aimed to construct an "alternative" or "parallel" ethnic heritage, in which "cultural forms were mobilized for ideological purposes” (Nuala C. Johnson 164). BWR heritage fiction (i.e. novels tapping into the black folklore) was steered by the cultural activity of the period, including such movements as Afrocentrism and womanism, but first and foremost, it was a response to the political exigencies of the times. These included the racial politics of President Ronald Reagan (1981-89), whose administration attacked welfare and affirmative action programs, and refused to enforce antidiscrimination laws. The BWR and Afrocentrism could be also seen as a reaction to the problem of the so-called black "underclass" that came into being as a result of the development of the crack cocaine economy. ${ }^{48}$ The decline of black communities in big urban centers was often attributed to the loss of cultural roots and identity, and led to much talk about a crisis of inheritance or a threat of disinheritance among African Americans. It was these developments, and the feelings of insecurity that they sparked, that led to the re-emergence of black cultural nationalism and a renewed interest in black tradition and folklore. African heritage became a pillar of the Afrocentrism that called for a rejection of drug culture, and the adoption of conservative black family values and an African-derived sense of identity. The heritage writing of the Afra American Renaissance, rooted in the folklore of the extended Caribbean, was part and parcel of this volatile political climate and the wide-spread debate about the crisis of African

48 The image of a largely black underclass, which was dependent on welfare, prone to criminality, had too many children, and at too young age, was enhanced by books such as Charles A. Murray's Losing Ground (1984), and William Julius Wilson's The Truly Disadvantaged (1987) and by mass media. In 1977, Time magazine's cover read: “A Minority within a Minority: The Underclass,” and on January 25, 1986, CBS news showed a highly-regarded documentary "The Vanishing Black Family - Crisis in Black America” (1986) by Bill Moyers. 
American culture and the problem of the black underclass. The heritage writing of the BWR sought in the folk past a corrective and antidote to black people's low "selfesteem," a problem which, next to racism, was perceived as the root cause of the social ills that plagued African American communities at the end of the 20th century (Austin, Achieving Blackness 138).

Algernon Austin states that Afrocentrists in particular thought that "the social problems facing blacks in the late 20th century stemmed from a lack of proper values," and, therefore, contrary to the "Black Power leftist critique of the political economy of capitalism" in the 1960s and 70's, they did not advocate "African Socialism” (ibid. 130). He argues that Afrocentrism was driven by the black middle class who deliberately diverted attention from social inequalities to heritage and cultural matters:

[t]he academics, intellectuals, and educators who produced Afrocentric scholarship and ran Afrocentric educational initiatives were all middle class. The black middle class was more likely to have the financial resources and the cultural knowledge to practice Afrocentrism best. They were likely to be most knowledgeable about authentic African names, authentic African textiles, and authentic African art. Kwanzaa's ${ }^{49}$ increased popularity was the result of the actions of middle-class women. It was the black middle and upper class who could afford to take the expensive trips to Africa. And the Black middle class was overrepresented at the Million Man and Million Woman marches. In the Afrocentric era, the middle classes showed that it is incorrect to think of black nationalism as only a lower-middle class phenomenon. (Ibid. 170)

While BWR writers did not participate in what Cornel West termed "the black middleclass hoopla" of the Africanist era and its unproblematic glorification of African states and civilizations ("The Paradox" 32), their recourse to African American heritage constitutes another side of that black nationalist revival. It also seems to have been inspired by the same middle-class concerns: uneasiness about the state of African American communities and the writers' uncertainty about their own relations to the black masses they wished to represent. The status of the BWR within black communities had been undermined not only by decades of stereotyping of black women and the black nationalist backlash against their writing in the 1970s, but also, I think, by these middle-class writers' own growing sense of alienation from their roots - their working-class or peasant background.

A good example of a writer who was trying to come to terms with this ambivalence is Alice Walker, a Southerner who moved North, assimilated and became middle-class. Walker believed that the experience of migration North had fragmented and split her people, but that the reverse journey South could repair that rift. Like her protagonist, Meridian, who went South to search for "the people" (Meridian 31), Walker took trips back South because she believed in "the symbolic equation of South

49 Kwanzaa is an African American and Pan-African holiday which celebrates family, community and culture. 
and community" (Dubey, Black Women Novelists 139). She also wanted to be perceived as a Southern writer because, as Dubey says, "what the Southern writer inherits as a natural right is a sense of community" (Black Women Novelists 139). According to Sadoff, therefore, Walker "[sought] her rural, southern heritage with an idealism that temper[ed] and compensate[ed] for her own lost past. But she [found] as well cultural disinheritance, symptomized by black cooperation in the neglect of African American literature and black women's writing” (“Black Matrilineage” 14). To compensate for that rupture, Walker not only idealizes the idea of matriliny itself, but also the writer she considered her "foremother," Zora Neale Hurston. Walker reads Hurston's Mules and Men to the members of her family who "rapidly forget ... their southern cultural inheritance," in order to "[give] them back all the stories they had forgotten or of which they had grown ashamed of (told us years ago by our parents and grandparents)" (Sadoff 6). Readers of In Search of Our Mother's Gardens are told that Walker's relatives react with a joy that is difficult to contain:

No matter how they try to remain cool toward all Zora revealed, in the end they could not hold back the smile, the laughter, the joy, over who she was showing them to be: descendants of an inventive, joyous, courageous and outrageous people: loving drama, appreciating wit, and, most of all, relishing the pleasure of each other's loquacious and bodacious company. (85)

This compels Walker to fight for the memory of Zora, and to restore her to her welldeserved place in the canon of African American letters (ibid. 85, 87). But in accomplishing that mission, Walker ignores the fact that because of Hurston's Northern education and the "spy-glass of Anthropology" (Hurston, Mules and Men 1) that distanced her from the object of her research, Hurston was a "folklorist" but not a genuine Southerner. Walker, therefore, intentionally disregards what Sadoff calls "the scars of disguise and concealment” (18) in Hurston's prose that many of Hurston's critics have pointed out. ${ }^{50}$ Walker's adulatory account of Hurston's life and work ignores what Sadoff has described as "Hurston's much criticized and problematic eccentricity, her posturing and evasions” (ibid.).

In The Jamaican People 1880-1902: Race, Class and Social Control, Patrick Bryan explains, using the example of Caribbean national cultures, how such middle-class alienation inevitably leads to a revalorization of folk heritage. He claims that in the West Indies, as elsewhere in the colonial and postcolonial world, admittance to the middle class depended on the successful acquisition of Victorian manners and morals, and the rejection of what Toni Morrison called, in The Bluest Eye, the "funkiness" of native black cultures. According to Bryan, this shift in cultural allegiance produced in black intellectuals an anxiety about their own cultural authenticity. The black middle class recognized that the rural working class, which identified with suppressed and

50 See for example Robert E. Hemenway’s Zora Neale Hurston: A Literary Biography. 
vilified African-based customs, represented an oppositional ideology that offered a genuine alternative to white mainstream culture. That is why, according to Edmondson (Making Men, 60), so many African American and Caribbean immigrant novels, written by well-educated middle-class authors, are concerned with returning to the peasant societies of the extended Caribbean.

The return signifies a re-valuing of unsullied black folk origins and cultures, which are then seen as constituting "a prelapsarian image of the nation" (Edmondson, Making Men 60). These cultures become a point of departure from which the nation's historical progress is imagined and a platform from which a critique of western modernity is launched. In other words, as Edmondson puts it, "the imagined community of the nation must reside in that portion of it [that was] least influenced by colonialism: the folk, or peasantry" (ibid. 62). Claiming allegiance with the folk, as the source of the authentic cultural essence of the nation, is a common tactic used by nationalists to mobilize the masses to achieve common political goals. Therefore, while nationalism is "an urban movement," argues Edmondson, "it identifies with the rural areas as a source of authenticity, finding in the folk heritage the attitudes, beliefs, customs and language to create a sense of national unity among people who have other loyalties" (Bruce King, qtd. in Edmondson, Making Men 62). However, this should not blind us to the fact that conflicts of interest between different in-groups within a nation continue to persist, and that the nationalist middle class is, in fact, the group that is most susceptible to the western values that it critiques and strives to reject. As Edmondson remarks, "it is the very promulgators of this return to authenticity who are themselves the intellectuals most likely 'to be influenced by foreign ideas"” (ibid.).

This idea has been developed by Paul Gilroy, who argued in The Black Atlantic: Modernity and Double Consciousness that looking to folk heritage for national selflegitimization is indeed the result of western influence. His study demonstrates how Afrocentric thinking about race, culture and heritage in the 1980s was influenced by Enlightenment ideas and Romantic concepts of "race," "people" and "nation." Gilroy provocatively contended that the intellectual heritage of Euro-American modernity determined the manner in which African American elites understood nationality. Despite their frequent critiques of modernity, declarations about its state of crisis and professions of its eclipse, claimed Gilroy, the black middle class of the 1980s continued to theorize about the process of identity formation in concepts taken from the white tradition that they overtly discarded. He stated that they often emphasized ancestry or roots as the foundation for identity, instead of thinking of identity as an ongoing quest in both spatial and spiritual terms. In Gilroy's own words, “modern black political culture has always been more interested in the relationship of identity to roots and rootedness than in seeing identity as a process of movement and mediation that is more appropriately approached via the homonym routes" (The Black Atlantic 19). This quest for roots, or stable and presumably authentic forms of subjectivity and identification, has been the main strategy for "nation" building and racial 
uplift ever since the post-emancipation period. In The Black Atlantic, Gilroy argues that the Euro-American tradition of thinking about identity and nation taught African American artists, writers and theoreticians to accept a modern western concept of identity as something grounded in roots, folk heritage, racial and ethnic authenticity.

Timothy Brennan also argued, in "The National Longing for Form," that the concept of "folk character" originated in English Romanticism, which utilized the idea of the peasantry for political expediency. What is more, Brennan observed, the rise of nationalism and the elevation of folklore to the status of authentic national culture was accompanied by, and actually achieved through the rise of the novel as a medium through which the middle classes spread their nationalist ideas (48). Consequently, one might argue, applying Anthony Appiah's comment about the Nigerian penchant for "village novels" to the case of BWR heritage writing, that "fewer things ... [were] less native than nativism in its current forms" (Appiah, "Out of Africa” 145-6). ${ }^{51}$

\subsection{The "Spacetime of Heritage" and Black Women's Renaissance Narratives of Immersion}

BWR novels of the 1980s also witnessed a proliferation of "village novels," as championed most notably by Toni Morrison, who argued that since black people are "generally viewed as victims, wards, and pathologies in urban settings [rather than] participants," they don't feel that they belong to the city in the same way as white people, even the "poorest white factory worker or white welfare recipient" ("City Limits, Village Values" 37). While Morrison conceded that the city was not always an uninviting place for black people, she suggested that what made it on the whole into a place of alienation for them was the absence of a black ancestral presence. It is for this reason, she claimed, that "the city has huge limits and the village profound values" (“City Limits, Village Values" 29). The village, cut off from civilization, modernization and the encroachment of capitalist values, is the place where the "advising, benevolent, protective, wise Black ancestor is imagined as surviving” (ibid. 38)

The multiple articulations of the pastoral/volkish/village novel that emerged from the BWR in the 1980s, which was grounded in ancestry and roots and seen as being conducive to the survival of black essence, reflected and refracted the ideas of both Africanists and womanists. Catherine A. John, in Clear Word and Third Sight: Folk Grounding and Diaspora Consciousness in Afro Caribbean Writing, states that "all great art is derived from the folk" and informed by "the very old truth-speaking tradi-

51 See a similar critique by Wendy Griswold in "The Writing on the Mud Wall: Nigerian Novels and the Imaginary Village," where she claims that the "village novel" is a form that arose from the specific historical circumstances of global cultural production, and reflected the political and economic realities and interests of the cultural elites. 
tions from the ancient mother-culture: the fables, the parables ...” (7). This assertion aptly summarizes the spirit of the BWR heritage fiction that elevated the status of both debased folk cultures and their "keepers"; namely, simple peasant women. Narratives such as Mama Day, Praisesong for the Widow, Abeng and No Telephone to Heaven feature indomitable old women, who are the principal agents of a mythical and reinvented primordial motherland. They are what Stratton called, in another context, "emblem[s] of communalism but also of active resistance to exploitation and oppression” (Stratton, Contemporary African Literature 49). By comparison with the 1970s' stereotypical grandmother figure, such as Momma Henderson in Maya Angelou's I Know Why the Caged Bird Sings, who had recognizable physical and psychological traits, the community and blood mothers of the 1980s are folkloric figures with ties to ancestry, roots and nature.

As I have argued in the previous chapter, female folk characters, such as Aunt Cuney in Marshall's Praisesong for the Widow, Gloria Naylor's Mama Day, and Miss Mattie in the Clare Savage novels, are "midwives of the 'national' soul," to misquote McClintock (Imperial Leather 303). As venerable blood-or-other mothers, these women preserve the essence of the African American way of life and pass on distinctly black and feminine cultures. Privy to this maternal legacy, the daughters are appropriately armed to negotiate their identity in relation to their respective motherlands (America, Jamaica or England). The mothers' reverence for their native culture/ motherland is not always so obvious and easy, however, particularly for daughters and granddaughters who occasionally give in to other competing worldviews and cosmologies, such as these associated with Euro-American culture. For these prodigal daughters, the female elders act as "rural agents of change," to misquote Stratton again (Contemporary African Literature 49). Hailed by their communities as healers and conjure women, they bring the younger women back to the tribal fold and restore their connections to what Annis Pratt has called the "green world" (Archetypal Patterns 75).

It is interesting to note that for BWR writers the setting for that idealized green matriarchal world is always, as I have argued earlier, the extended Caribbean, a home-site connected to African cultural practices and aesthetic traditions. The extended Caribbean signifies slave societies that developed on the basis of cotton, sugar, or coffee plantations, where "the agrosocial system of slavery developed in its fullest and most harsh form" (Lewis, Main Currents 2). Similarly, Harris has described the extended Caribbean as "the land of blood and death, of slavery, of countless generations of Africans tied to brutal and unrewarding labor, of intangible instead of tangible wealth" (Fiction and Folklore 96). It is a mythical territory, famous for its magic, and for the conjuring traditions of Vodou, Obeah, or Santeria that were described and popularized by "the genius of the South," the great foremother Zora, whose 1937 novel, Their Eyes Were Watching God "articulate[d] the recovery of Caribbean culture" (Willis, Specifying 48). For BWR writers, whom Toni Cade Bambara tellingly calls "Sisters of the South," the extended Caribbean is a place where the myth of the nation 
finds its territory and its boundary in the form of iconic culture-bearing women and the "archetypal imagery of common folk" (Braxton, "Ancestral Presence" 314).

This privileging of the extended Caribbean as the site of an authentic black culture bears out Cosgrove and Daniels's thesis that heritage writing has both a temporal/historical and a spatial/geographical dimension (1-10); what David Crouch called the "spacetime of heritage" ("Affect, Heritage, Feeling” 185). In other words, heritage is articulated both as an exemplary historical narrative (which I will discuss in the following chapter) and as a traditional landscape..$^{52}$ As Higson argues in English Heritage:

When heritage culture is mobilized on a national scale ("our shared national heritage"), it is in this spatio-temporal grid that the nation emerges as a unique, organic, meaningful community. The discourse of heritage ensures that the national community is bound temporally, by traditional historical narratives, and spatially, by a geographical vision of the nation. (50)

In the BWR novels of the 1980s, the idea of the nation was inseparable from that of the traditional Southern landscape. This traditional setting was treated as the place of origin and a key point of reference; in brief, a homeland, or, more precisely, motherland, which was usually looked upon with yearning and nostalgia. For example, Denise Heinze has pointed out that in Morrison's fiction, all the "communities that have more successfully retained ethnicity and a measure of independence are located in the South" (The Dilemma 108). She cites "Shalimar, Virginia, Pilate's Virginian Island Colony, Eloe, Florida" as examples of these communities, (ibid.), and one might also add to this list also the wild part of the Isle des Chevaliers (Tar Baby). These are all rural communities situated in the extended Caribbean, which, in spite of oppression, hardship and poverty, have more integrity than northern black communities. Whereas northern communities, such as Lorain in The Bluest Eye, are more susceptible to the ideology of the American dream, such as consumerism, western ideals of success and beauty, the South is depicted as a place of spiritual fulfillment and magic, where "authentic" black communities can still be found.

Indeed, the concept of "community" itself gained traction in the 1960s and 70s, when it was practically reinvented as a positive term to describe "what was always there, only we [African Americans] called it the "neighborhood"” (Stepto, "Intimate Things in Place" 10-11). In the 1980s, it was further valorized by the heritage debate, along with its attendant tropes of participation, dissonance and identity. ${ }^{53}$ The $1980 \mathrm{~s}$ novels depicted folk communities from the South as central sites of ethic/national identification. Carriacou, (Praisesong for the Widow), Shalimar (Song of Solomon) and

52 See: Stephen Daniels's Fields of Vision: Landscape Imagery and National Identity in England and the United States.

53 See Harrison, "The Politics of the Past." 
Willow Springs (Mama Day) are semi-mythical collectivities, not located on any map. They are idealized venues, "isolated communit[ies] with air that is pure, even primal, [they have] maintained an Afro-centric view point” (Rody, The Daughter's Return 60). Drawing on Benedict Anderson, Thorsson argues that "removing" these localities from the map reverses the colonizing process that routinely began with "mapping, followed by census and finally building a museum," the aim of which, according to Anderson, was "to drain sacredness from the ritual objects and practices" (Thorsson, Women's Work 95). Unmapped and undocumented islands and neighborhoods "resist [such] a theft of meaning" (ibid.). Writing about Mama Day, Thorsson states that these mythical collectivities exist outside colonial history and dominant power structures; not incorporated in any nation-state, they constitute "a nation unmoored from governmental institutions and political structures, rooted instead in social relations and local daily practices" (ibid. 116). As such, they have an amorphous polity which is "not so much about nationhood as about peoplehood, not so much about structures as about solidarities" (Hahn 473, qtd. in Thorsson 116). Even though they do not replicate nation states, however, Thorsson cautions that they "[rely] on the logic of nationhood." In the words of Gloria Naylor, they are a "microcosm for building a nation"” (Smith and Naylor, "An Interview” 1435).

Naylor's narrative in Mama Day is preceded by her own map of Willow Springs and the main characters' family tree, which are, in the words of Daphne Lamothe, "tropes conventionally used to signify a cultural nation" ("Gloria Naylor's Mama Day" 159). Willow Springs is like a miniature of a nation (Bonetti, "An Interview with Gloria Naylor" 45), with its own history (or rather herstory), as indicated by the family tree and a bill of sale detailing the purchase of a female slave suspected of using witchcraft, which suggest that this history was shaped by "a peculiar past that springs from that peculiar institution of slavery" (Bellinelli, "A Conversation” 107). The miniature nation exists outside official historiography and experiences time as eternity and stillness, as the collective narrative voice of Mama Day says. In Willow Springs there are no clocks or calendars, which are described as the "crude ways to order our realty" (ibid. 158); instead nature, crops and seasons impose order on life. Thus, Willow Springs' time is cyclical rather than linear. "It is a place where so much is cyclical that even the live oaks in the graveyard sand in a circle" (ibid. 139), says George, a "foreign" visitor on that island that is "ripe for myths" (ibid. 218). For George, an orphaned and uprooted New Yorker, Willow Springs becomes "a redemptive place" (Ashford, "Gloria Naylor" 77) and a spiritual base "where people who have lost their way might come back to themselves," to quote bell hooks out of context (Yearning 225). Still, the island remains illegible (and even lethal) to George and other westernized outsiders, like the locally-born but brainwashed ethnographer, who returns to the island to collect local folklore through the "spying glass" of anthropology.

Travel within the spatio-temporal grid of heritage is, as Robert Stepto has shown in From Behind the Veil: A Study of Afro-American Narrative, a recurrent motif in African American literature. Narratives of immersion in the space-time of black heri- 
tage are all about the difficult art of making the South intelligible for assimilated and educated blacks, such as Alice Walker. The immersion narrative, according to Stepto, is about re-learning the grammar of "tribal literacy"; it "is a response to the loss of cultural identity entailed by the ascent [moving North]. The protagonist of the immersion narrative finds sustenance by a return to cultural roots, represented by the South, the family and folk community... [and] ... by African American musical traditions or historical discovery" (Lynn Scott 36). Immersion is achieved, then, by a reversal of the trip North that African Americans took with the aid of the Underground Railroad during slavery, and independently during the Great Migration. It is a return to the point of departure in order to recapture the essence of black culture, to overcome a sense of alienation, and to regain membership of the "tribe." 54

Unlike earlier African American narratives, which could have properties of both immersion and ascent simultaneously, the BWR rendering of the trope is much less complex. In the 1980s' novels, in which the "repatriation" to the village is at the heart of the plot, the extended Caribbean is invariably presented as the source of cultural essence, the location of "authentic" blackness, and a ritual landscape. Contrary to Du Bois's The Souls of the Black Folk (1903), which Stepto cites as an example of the unsolvable dilemma of double consciousness that cannot be resolved by either ascent or immersion (qtd. by Heinze, The Dilemma 108), the BWR figuring of this metaphysical geography clearly tips the balance away from the idea of a hybrid form of African and American identity and towards that of a folk African form. BWR narratives of the 1980s were the exact opposite of the narratives of ascent, in which the main character (often a man) progresses from the country to the city. Whereas for the male protagonists of ascent narratives, the city is, to misquote Boehmer, "a site of achievement of modern nationalist self-awareness" (Stories of Women 68), as, for example, in the 1960 's BN discourses that pictured the Northern ghetto as a crucible for a new masculine identity, for the female protagonists of Afra American novels, the South is the place for spiritual redemption and regeneration. ${ }^{55}$

Morrison's Song of Solomon was a prototype of the national allegory of immersion and rebirth. Like most postcolonial national allegories written by men, it features a male hero, Milkman Dead, as the son of the nation. Unlike George in Mama Day (1988), who fails to acquire tribal literacy and dies, Milkman undergoes a successful re-education and is admitted by his tribe. Morrison's Tar Baby juxtaposes the personal integrity of the son of the nation, Son, who remains well-versed in tribal lite-

54 According to McDowell, there are also narratives of hibernation, in which the quest takes the male protagonist "underground." It is a "descent into the 'underworld' and is primarily political and social in its implications. Ralph Ellison's Invisible Man, Imamu Baraka's The System of Dante's Hell, and Richard Wright's 'The Man Who Lived Underground' exemplify that quest” (McDowell, "The Changing Same" 14).

55 See, for example, Alice Walker's "The Black Writer and the Southern Experience," which describes narratives of reverse migration to romanticized southern folkways. 
racy, with Jadine's inability and unwillingness to learn the basics. This novel, more than any other 1980s narrative, shows that the idea of ascent was anathema for the womanist writer. Whereas black female quests to the South were usually presented as "personal and psychological” journeys from "victimization to consciousness," as McDowell has noted ("The Changing Same” 14), Jadine’s abortive quest is, as I argued in the previous chapter, a traumatizing experience that undermines her self-esteem and deepens her sense of isolation. Jadine is not susceptible to the romantic, pastoral and exhilarating vision of the South, which Alice Walker describes as "feeling the soil between the toes, smelling the dust thrown up by the rain, loving the earth so much that one longs to taste it and sometimes does" (“The Black Writer" 21). She has no appreciation for the sentiments and worldviews of common, often illiterate, black folk, and sees black Southern culture merely as a "stock of particularisms" (Fanon, qtd. in McDowell, "The Changing Same" 114), which she blames for having made Son so impractical and uncompromising. She also rejects a vision of black womanhood that equates women with the organic and the natural and treats them as a reservoir of intuitive collective knowledge. Jadine is resoundingly condemned for rejecting this vision, and thereby serves as a proof of the idea that when heritage turns "predatory," that is when it eliminates other experiences to honor one true culture inherited from the past, "[a]ll too often the doors of tradition are slammed in women's faces" (McClintock, “"No Longer in a Future Heaven”” 122).

Marshall's Praisesong for the Widow, on the other hand, is a perfect example of the archetypal journey of initiation into "tribal literacy," in which "an unapologetic bourgeoise” Avey (Marshall, Triangular Road 147), "travels, both literally and figuratively, toward African American cultural nationalism” (Thorsson, Women's Work 86) and metamorphoses into an "articulate kinswoman." Avey, the titular widow, is marooned on Grenada after she cut her cruise short following a nightmare about her late relative, Great Aunt Cuney. Her name, Avey, is short for Avatara, a Sanscrit name for a reincarnation of a deity whose mission is to confront the evil of the world. The name was given to her by her foremother, Gran, the heir of legendary Ibos, "pure-born Africans" (Praisesong 37), who walked on water back to Africa having rejected New World enslavement. The unwritten oral story of their magical, biblical-like departure is kept alive and passed on by women in Avey's family, but Avey betrays this maternal ancestral heritage by investing in another myth, that of the American dream of material gain and social uplift, which leads to the dissolution of both her marriage and her identity.

When Avey is persuaded to take a boat trip to the smaller nearby island of Carriacou, her journey of immersion is about to begin. The Carriacou Excursion is an annual ritual of remembrance of the old African "nations," or, rather, "a few names of what they [locals] called nations which they could no longer even pronounce properly, the fragments of a dozen or so songs, the shadowy forms of long-ago dances and rum kegs for drums" (Praisesong 240). Avey is to learn that these "subliminal memories ... over the years had proven more durable and trustworthy than the history 
with its trauma and pain from which they had come. After centuries of forgetfulness or even denial, they refused to go away" (ibid. 245). As a result of her immersion, Avey starts to appreciate these feeble memories, "[t]he bare bones. The burned-out ends," that the Carriacou people "clung to ... with a tenacity she suddenly loved in them and longed for in herself" (ibid. 240). She vows to share that ancestral wisdom with "those young, bright, fiercely articulate" young people in the North, who are in need of tribal literacy because without it they are "unaware, unprotected, lacking memory" (ibid. 255). As an "articulate kinswoman," Avey becomes a skilled and active user of her cultural resources, who can draw on traditional cultural repositories in search of the tools, capacities and strategies with which to respond to the political and social expediencies of her environment.

During the excursion, Avey's mind is made to "swing like a pendulum gone amok" (ibid. 323). Her boat trip to Carriacou is reminiscent of the Middle Passage; it is an ordeal after which she is purged and reborn. She receives spiritual healing from women named Ancestress and Mother, who personify Avey's symbolic mothers and the mother-island. ${ }^{56}$ They prepare her for reunion with her tribe and relieve her of the trauma of unbelonging. Avey's re-learning of tribal literacy involves paying homage to the "Long-time People" (ancestors), the Caribbean and the motherland, and appeasing Aunt Cuney and begging her forgiveness for not honoring the Ibos or spreading the gospel of the Ibo Landing. Finally, it means recalling and performing her "nation" dance and participating in other Creole dances and "sorrow songs" that evoke slavery, the loss of life and heritage, and yearning for an impossible reconnection with Africa and the pre-slavery past (ibid. 244). These rituals make Avey whole again; she becomes Avatara, one of "ancient spirits who bridge the geographic and cultural diaspora.... These are deities who Avey will eventually come to honor through her choice to become a teller and to pass on her ancestors' story" (Holloway, Moorings and Metaphors 134).

Some critics have argued that Praisesong for the Widow presents a model of diasporic, rather than national consciousness. Eugenia Collier, for example, wrote that Praisesong "links the Black individual with Black people worldwide, showing a vast multitude of people sharing a common past and, by necessity, a common future, in which the individual is made whole only by awareness and acceptance of this massive community" ("The Closing of the Circle" 296). Thorsson claimed that the novel "dismantles the stereotype of Africa as a timeless monolith" (Women's Work 93), as the people "practice" their nation by participating in dance rituals that are from different African "nations," such as Cromanti, Iboand Manding, for example. Finally, Abena

56 Missy Dehn Kubitschek argues that even Lebert Joseph is feminised in the novel. He is an incarnation of Legba, a dual-gendered African God of nurturing, protecting and ensuring continuity. "Even Lebert becomes female during the dance. Clearly female forces serve as midwives for Avey's rebirth into her true self, Avatara” (Kubitschek, qtd. in Thorsson, Women's Work 10-4). 
Busia, in "What Is Your Nation? Reconnecting Africa and Her Diaspora through Paule Marshall's Praisesong for the Widow," observed that the novel portrayed black people as twice displaced, from Africa and the extended Caribbean, and as spiritually unmoored and scattered around the world: "Marshall articulates the scattering of the African peoples as a trauma - a trauma that is constantly repeated anew in the lives of her children" (196-7) as with each new displacement, relocation or exodus (from Africa, from the Caribbean, from the USA) their alienation and uprooting become more profound and deeper. In spite of that broader historical and diasporic perspective, Thorsson has asserted, "Marshall portrays diasporic consciousness as a useful mind-set ... consolidating ... [an African American] nation apart within the United States” (88-9). This nation is determined by the shared history and culture of the black diaspora, and by transnational travel, which makes it possible for African Americans to "articulate the nation in opposition to the nation state" (ibid. 89).

However, many novels present the quest for tribal literacy without the characters embarking on real journeys of immersion. They treat what might be termed "Southerness" as an ethos that African Americans have in common by virtue of their participation in a set of cultural practices, or a state of mind that is cultivated through "small rites" (Praisesong 137), such as reciting African American poetry, listening to blues and Jazz, and dancing. These narratives seem to suggest that a sense of national consciousness does not have to be created exclusively through immersion in the ancestral landscape. These novels construct an idea of the nation that is based on "a spiritual principle" (Renan, "What is a Nation?" 19). This makes black tribal literacy "portable," to misquote Thorsson (Women's Work 111). Paule Marshall, Alice Walker and Gloria Naylor, in particular, are excellent examples of this portable cultural nationalism that is carried by "culture bearing" black women. According to Bonetti, Naylor was born in New York but was raised on the "codes of behavior," the speech, the accent, the worldview and "the sense of family" of her parents, who were migrants from the South ("An Interview with Gloria Naylor” 42). In effect, she retained her tribal literacy and was able to produce quintessentially volkish narratives, like Mama Day, which are permeated with nostalgia for the South and peopled with peasants tracing their roots several generations back. As Thorsson has suggested, womanist texts preached the ethos of cultural nationalism through various rituals in which culture-bearing women practiced their "portable" cultural nationalism, what Bambara has called the "inner nation" (The Salt Eaters 118). Cooking, for example, in Ntozake Shange's Sassafrass, Cypress \& Indigo, is just such a ritual. It is a female and ethnic skill that expresses Southern tradition, historical connections, and what Thorsson has called "the vast unknown lineage" (Women's Work 99), which connects back to "the slaves who were ourselves," as Shange puts it in Sassafrass, Cypress \& Indigo (224). Recipes are expressive not just of black female creativity and artistry but also, first and foremost, of tribal literacy. Other "repertoire[s] of knowledge" (Clark, "Archiving Epistemologies” 156) through which BWR writers fashioned portable heritage in their novels, included such diverse modes of creative 
expression as making dolls, weaving, dancing, conjuring, healing and, of course, mothering. These traditionally female occupations used resources that symbolized maternal legacy and lore, and emphasized the fact that the "inner nation" is a matrilineal tradition.

The national allegories written by most African Caribbean women writers have a different attitude to the space-time of heritage, and their plots fit into a different paradigm. Since these authors, as Curdella Forbes has observed, "exist behaviorally and psychologically on a continuum between nationalities and/or ethnicities" (From Nation to Diaspora 229), they also show great interest in ancestral folk heritage and the Caribbean landscape. The trope of the journey is also common in books written by Caribbean immigrant writers, which often present different legs of the character's allegorical wanderings, and symbolic "stations" in Africa, England, the West Indies or the United States. On the other hand, however, their trajectories rarely fit neatly into the ascent/immersion paradigm (with the exception of Marshall's Praisesong for the Widow and Kincaid's novels, which I discuss later). Instead, the novels chronicle multiple journeys and feature lots of cyclical departures and arrivals. In this way they commemorate routes rather than roots and expose the displaced historicity of the African Caribbean. For example, Marshall's 1968 novel, The Chosen Place, The Timeless People, which was published before her classic narrative of immersion, Praisesong for the Widow, had its female protagonist "land" on all three motherlands - Europe, Africa and the Caribbean. As Ogunyemi puts it, "Merle, carrying her national burden of leading Bournehills up a road to progress, recoups her energy after her bouts of insanity [in the colonial motherland] and strengthens herself spiritually for the future political struggle by undertaking a pilgrimage to East Africa” (30). Eventually, "recovers her sanity to play her part in an agricultural commune" of her Caribbean homeland (Ogunyemi 30).

While Marshall's and Lorde's narratives inscribed their characters' negotiations of African Caribbean female and exilic subjectivity within the tradition of African American writing that could be categorized as a "literature of reconnection" (Fido, “Textures of Third World Reality" 42), Kincaid's and Cliff's allegorical novels picture the Caribbean motherland as what Lemuel. A. Johnson has called "the (com)promised land" ("A-beng" 126), where the "womanchild" is doomed to a lot of suffering (ibid. 127). As I have contended in the previous chapter, Cliff and Kincaid are directly engaged in postcolonial and anti-hegemonic criticism of the motherland(s), and their imaginative re-workings of mother/daughter tensions can be read as bildungsromane that are "metonymic of the colonial condition" (Ledent, "Voyages into Otherness" 59). As Curry has noted, Cliff's and Kincaid's narratives feature daughter-mother(land) relationships that are "uniformly allegorical of colonizer/colonized relationships" (qtd. in Bouson, Jamaica Kincaid 4). They concentrate on both the psychic development of the girl-child (her acquisition of appropriate gender roles) and the daughter's resistance to the mother, and also, by implication, on the colonial culture and the mother country. Consequently, there are no "mothers' gardens" or "folk storehouses" 
that these Caribbean daughters could easily tap into in order to confront the truncated or "bleached out" aspects of their African selves.

While Cliff's narratives do actually endeavor to follow the same impulse as the African American literature of reconnection, her novels, particularly No Telephone to Heaven, can hardly be considered as successful narratives of immersion. Although Clare loves the countryside and her black grandmother, Miss Mattie, in whose house she goes through all the formative experiences of her life, she never gets to access the "inner nation" or to acquire African Caribbean tribal literacy because of her light skin. In St. Elizabeth, Clare often feels "locked off" (No Telephone 154); she is not allowed to participate in the rituals of her grandmother's church or socialize with country women. She gradually becomes more and more aware of the unbridgeable gap that separates her from her only playmate, Zoe, who, unlike Clare, is a daughter of a poor, dark-skinned peasant woman. At the end of the novel, the reader is told that Clare, now a revolutionary, reclaims "her grandmother's land" and restores "ties [that] had been broken" (ibid. 91; 103), and has thus become "an articulate kinswoman.” But her journey of immersion into the ancestral landscape ends tragically with Clare being literally "burned into the landscape" by a barrage of bullets coming from the Jamaican military (Cliff, “Caliban's Daughter” 45). In this way, as Toland-Dix argues, the damage done to Clare, "who has been rejected, abandoned and dismissed by the matrilineage by which she so longs to be acknowledged" ("Re-negotiating" 21), seems to be irreparable. Her efforts to immerse herself in the space-time of her African Caribbean heritage are futile: "She does not reclaim the spiritual power that had led Miss Mattie to create her own church and become a spiritual force of her community" (ibid. 24). Her death, one might even argue, represents Jamaica being overwhelmed by neo-colonial forces.

Kincaid's Lucy does not become an "articulate kinswoman” either, nor does she want to become one. Her journey, quite untypically, is one of ascent, and at the end of it, Lucy consciously chooses to remain an articulate survivor. The novel, which could be described as a Künstlerroman about Kincaid's own path to becoming a writer, tellingly ends with Lucy starting a memoir, the first sentence of which expresses the pain of her self-inflected exile: "I wish I could love somebody so much I could die from it" (Lucy 163-164). Loneliness and alienation are the price Lucy pays for her hard-won independence. "I was alone in the world," she claims. "It was not a small accomplishment and I thought I would die doing it. I was not happy, but that seemed too much to ask for" (ibid. 161). Lucy escapes the colonizing mother(land) to become a transcultural traveler and a teller of radical stories, albeit one whose integrity is won at the expense of "the awful emptiness inside" (ibid. 8). She stands alone, rejecting all the comforting certainties offered by the Kulturnation of unique black communities bound by vernacular cultural practices expressed through the black idiom.

Annie, Lucy's younger self, still gratefully receives support from the green matriarchal world of the mother-island. Her maternal grandmother, Ma Chess, a foil for Annie's mother and her genteel aspirations, is Kincaid's take on the trope of the 
wise grandmother; she is "a model of African based female power, that of the Obeah woman” (Simmons, Jamaica Kincaid 31-32). She embodies the vibrant energy of the native culture, resisting both colonial and patriarchal domination. Ma Chess links Annie to the island's pre-Columbian past and African cultural practices in order to nurse her back to health after her feud with her mother results in a severe nervous breakdown. But Lucy is determined to move out of the "Kumbla" of the "folk storehouse" and the island itself. According to the Jamaican writer, Erna Brodber, the "Kumbla" or "calabash" - a container used to protect precious objects - signifies both a protective and a confining space (Walcott 334). Coming out of "the Kumbla" describes the process of moving out of confinement into visibility and articulation, which is Lucy's ultimate goal. This signifies that Lucy (representing Kincaid herself) does not need the tribe and its reassurance to be an independent whole. As a diaspo$\mathrm{ric} /$ migrant woman writer, and an expert at "cosmopolitan rootlessness" (Boehmer, Stories of Women 226), Kincaid and her fictional alter-egos use their freedom to reinvent a new Black Atlantic and feminist epistemology.

\subsection{Black Conjure Women as "Midwives of the 'National' Soul”}

In African Caribbean folk narratives, wise older women are also "the site of identification," to use the expression coined by African Canadian poet Dionne Brand. They are, too, "midwives of the "national' soul" (McClintock, Colonial Leather 303) and repositories of spiritual beliefs and practices that are instrumental in keeping their unique, organic, black communities alive. Cliff elaborates on her use of the trope of the powerful grandmother in her essay "Clare Savage as a Crossroad Character," stating that "the powerful aspect of the grandmother originates in Nanny." She adds:

at her most powerful, the grandmother is the source of knowledge, magic ancestors, stories, healing practices and food. She assists at rites of passage, protects and teaches. She is an inheritor of African belief systems, African languages. She may be informed with ashe, ${ }^{57}$ the power to make things happen, the justice. (267)

The half-historical, half-mythical Nanny was a Maroon leader and an Obeah woman, who could allegedly catch bullets with her buttocks. She is the heroic national mother of the better, non-conforming and culturally resistant part of Jamaican society. According to Braxton, Nanny and Momma Henderson (in Maya Angelou's I Know Why the Caged Bird Sings) "are versions of the same Afra American archetype, both are products of myth making and reflect the people's need for heroes who embody cultural

57 A Yoruba word meaning power, command, and authority. 
values necessary for the survival of the group. Both figures transcend the generations to become "timeless people”" (“Ancestral Presence” 304).

But the community mothers and griots of Caribbean women writers are not as powerful as their womanist counterparts in African American women's fiction, such as Mama Day, The Salt Eaters and Praisesong for the Widow. By and large, Cliff's narratives lament the denigration of the once formidable Obeah women in modern Jamaica. In No Telephone to Heaven, their loss of prestige is symbolized by their social ostracism and ultimately their tragic death when the asylum in which they are kept is deliberately set on fire. ${ }^{58}$ As Braxton argues, therefore, although the wise grandmother is a universal figure of resistance who is found in the folklore and fiction of all communities of the black diaspora, the African American and African Caribbean grandmothers are not endowed with the same degree of authority. The Clare Savage novels show that the Jamaican community mothers are not without blame, since their fall from power was at least partially of their own making. Even though Nanny does find worthy heirs in such heroic figures as Mma Alli, Inez and eventually Clare herself, one cannot help but notice that while the novels eulogize Nanny, Mma Alli and Inez, at the same time they also censure the failings and faults of contemporary blood-and-other mothers who have rejected the legacy of the indomitable spirit of Obeah women of the past.

For example, Clare's maternal grandmother, Miss Mattie, retains some vestiges of the powers held by the powerful Obeah women of the past, and is revered by her rural community as a repository of an ancient African worldview. Thanks to her, St. Elizabeth, where she lives and where Clare spends her holidays, is a female environment saturated with an indigenous African culture, in which women, not men, are political and spiritual leaders. Cliff shows Miss Mattie as a cornerstone of the community and heir to Nanny's spirituality. Miss Mattie establishes and presides over her own church and allows some of the poor landless proletariat to squat on her estate. She is described as a "sorceress" who, through charitable acts that are reminiscent of Nanny's feats, performs for the poor "the miracle of loaves and fishes" (Cliff, No Telephone 5).

However, Miss Mattie's sagacity is undermined by Cliff's desire to show that even this green maternal world is vulnerable to colonial pressures, most notably western notions of colorism, materialism and social hierarchy. Like the rest of Jamaican society, the rural community of St. Elizabeth is divided according to race, class and ownership of private property. Miss Mattie's family, the Freemans, are lucky to be

\footnotetext{
58 A similar motif appears in Edwidge Danticat's writing which reclaims the folkloric figure of the female vampire "soucouyant" as a paragon of agency for women of the African diaspora. Soucouyant wise women are persecuted and burned by Duvalier's regime. See Penier "Engendering the National History of Haiti in Edwidge Danticat's Krik? Krak."; and "The Formation of Migratory Subjects in Edwidge Danticat’s Krik? Krak!”; “The Black Atlantic Zombie: National Schisms and Utopian Diasporas in Edwidge Danticat's The Dew Breaker.”
} 
lower-middle-class landowners, even though they are black, and they willingly adopt the colonial hierarchies of class and possession. Among the women who attend Miss Mattie's church are those who, like her, are farm owners. Their social status is indicated by the jewelry that they wear and by the fact that they are admitted to Miss Mattie's house. At the bottom of the social ladder are the poor, unadorned women, who are recipients of Miss Mattie's bounty but are never allowed to enter her house. Furthermore, though Miss Mattie does not completely assimilate into the dominant colonial culture, she conforms to it by passing on to her offspring a selective knowledge of the past. Kitty does not learn from Miss Mattie about Mma Alli or Nanny; the whitish Clare is completely "locked off” from her maternal heritage. Therefore, Miss Mattie's charismatic public appearance is at variance with her classism, her willful historical amnesia, and her striking and inexplicable emotional rigidity towards her own children and grandchildren. Miss Mattie is as anti-maternal and un-nurturing as many other fictional Caribbean mothers.

Regardless of these differences, what connects African American and immigrant Caribbean BWR writers is that their narratives feature a similar "myth-symbol complex." According to Anthony Smith, who coined the term "myth-symbol complex" is an ensemble of pre-modern symbols, myths, values and traditions that connect modern nations to pre-modern "ethnie," the French word meaning ethnic groups. Examples of the myth-symbol complex in this context include tales such as those recorded by Hurston of the devil outsmarting God, blacks outsmarting Ole Massa, and animals allegorizing the black condition; and Marshall's Caribbean songs, wise sayings and dances that link the protagonists with African traditions, religions and beliefs (Praisesong for the Widow). Rituals of weaving, culinary and medicinal recipes, and herbal lore in Shange's Sassafrass, Cypress \& Indigo are also part and parcel of the black "myth-symbol complex," as is a children's rhyme that offers Milkman a key to the pre-modern past in Morrison's Song of Solomon. Conjure women and flying Africans, rituals of laying on of hands, healing, rootworking, ancestor worship, and midwifery, together with vernacular practices of storytelling, riddles, jokes, rhymes, musical motifs and call-and-response, are all part of the black diasporic myth-symbol complex. These tropes, which are present to a greater or lesser degree in most novels of the BWR, make up a contemporary heritage discourse that links the modern medium of the novel to the diasporic black "ethnie": sacrosanct traditions that constitute the timeless essence of the Kulturnation.

\subsection{Womanist Literary Criticism and the Development of "an Essential Black Female Matrix"}

As I highlighted at the beginning of this chapter, at the onset of the poststructuralist theoretical movement in the 1980s, there was a debate among primordial-essentialists and constructivists about how much of this residual "cultural stuff" is specific 
and fixed, and how much is constructed or invented (Chaterjee, qtd. in Yuval-Davis, Gender and Nation 41), with Anthony Smith occupying the middle ground between the two camps. In this "authenticity debate," essentialists clung to claims that the myth-symbol complex was real, whereas constructivists insisted on seeing it as "a contemporary manifestation of a longer historical process whereby human societies actively cultivate a social memory" (Johnson, "Heritage and Geography" 163). This dispute has been more or less resolved in favor of the poststructuralist constructivists. In "Heritage and Authenticity," for example, Helaine Silverman argues that:

$[\mathrm{u}]$ nlike previous scholarship that portrayed authenticity as a stable value/product, current research understands it as dynamic, performative, culturally and historically contingent, relative - a quality/tool that can be strategically configured and deployed according to the task at hand, be that social, cultural, economic, political, religious and so on. (69)

Consequently, while prior to the 1980s, the "heritage crusade" was inextricably linked to "an authenticity craze" (Silverman 69), since the 1980s there has been a consensus that writers, like folk storytellers, are engaged in the elaborate labor of "lying up a nation" (Hurston, Mules and Men 21). Most of the womanist critics of the 1980s were also "lying up a nation," as McDowell observed a decade later (McDowell, "The Changing Same” 118). Early black feminist critics, including Barbara Christian, Barbara Smith and Mary Helen Washington, found it extremely difficult to move "from the "Age of Criticism' to the "Age of Theory," (ibid.) and to poststructural/constructivist way of thinking about heritage. In effect womanist literary criticism was "another form of storytelling, of mythmaking," which determined "what ... [readers] see when they read and how they receive and represent what they read" (ibid.). It was thanks to these critics and their relentless "heritage crusade" that the volkish tradition became enthroned as the literary canon not just of black feminism but also of ethno-nationalism.

Multiple essays and interviews by African American women writers and critics strove to counter the idea that folk heritage was a construction. Toni Morrison is a good example of the sense of ambivalence that many BWR writers felt towards the issue of "authenticity." At times, Morrison acknowledges the discontinuity of black heritage, as when she mourns over the passing of the time when "an artist could be genuinely representative of the tribe and be in it" ("Rootedness" 341). She admits that is impossible to go back to that ideal because "[w]e [Africans Americans] don't live in places where we can hear these stories anymore; parents don't sit around and tell their children those classical, mythological archetypal stories that we heard years ago" (ibid.). Like Walker, who sought in Hurston's novels a remedy to cultural uprooting and deprivation, Morrison sees the novel as a means of reconstructing the broken connections with the ancestral past. She concedes that the novel cannot fully compensate for the loss of tribal traditions that has occurred in modern times, but maintains that it can create a semblance of temporal continuity between the present and the past by functioning as a "modern" substitute for folk storytelling, a contemporary way of cultivating social memories. Consequently, Morrison's novels strive to evoke in 
readers a sense of the historical depth of black experience by recycling "tribal" stories and archetypes. Likewise, her essay, "What the Black Woman Thinks About Women's Lib,” pictures contemporary black women writers as engaged in what McClintock elsewhere called "an invention of a tradition" through "elaborate labour of regeneration” (“"No Longer in a Future Heaven”" 106-7). In her essay, Morrison argues that the black woman "had nothing to fall back on, not maleness, not whiteness, not ladyhood, not anything. And out of the profound desolation of her reality she may very well have invented herself" (Morrison, qtd. in Charles Johnson, Being and Race 97). In fact, most BWR writers also "invented" their female characters by borrowing from the archetypal imagery of the common folk culture to create "innovative fiction and contemporary myths to sustain a struggling people” (Thorsson, Women's Work 314). Morrison, as Charles Johnson has observed, became the most accomplished purveyor of such "mytho-poetic narratives" (Being and Race 103), in which she skillfully manipulates "cultural archetypes" to create a usable politically-charged heritage that black women could "fall back on" (ibid. 102).

More often than not, however, Morrison's writing gives in to the "authenticity craze," as, for example, when she states that as a novelist she "blend[s] the acceptance of the supernatural and a profound rootedness in the real world ... with neither taking precedence over the other" and argues that this artistic strategy is not a magical realist or postmodernist "trick" but an indication "of the cosmology, the way in which Black people looked at the world" ("Rootedness" 342). In the following, often-quoted passage, Morrison asserts her belief that black people as a group have certain fixed racial characteristics that constitute a distinctively black worldview:

We are a very practical people, very down to earth, even shrewd people. But within that practicality we also accepted what I suppose could be called superstition and magic, which is another way of knowing things. But to blend these two worlds together at the same time was enhancing not limiting. And some of those things were "discredited knowledge" that Black people had; discredited only because black people were discredited and therefore what they knew was discredited. (Ibid.)

Morrison's essays do sometimes offer such sweeping generalizations as this, which present a totalizing view of the black "people" as "articulate kinsmen" by nature. In this way, Morrison endorses the idea of what Frantz Boas called the "Volksgeist,"59 an outdated, 19th-century anthropological concept, according to which culture is defined as a people's characteristics. While Boas separated his understanding of culture from any racial and demographic foundations and treated it as an autonomous abstraction, Morrison's essays and fiction attach it once again to racial identity and to rural lifestyle, ascribing to black people certain immanent and distinctive cha-

59 See George W. Stocking, Jr., ed., Volksgeist as Method and Ethic: Essays on Boasian Ethnography and the German Anthropological Tradition. 
racteristics. She presents black people as being bound together by a mythical episteme, the "discredited" knowledge that "has a very strong place in her [and their] world” (Morrison, "Rootedness” 342).

As I have stressed throughout this study, this approach to black heritage was a 1980s' phenomenon. There is a marked difference between the ways in which black folklore was treated in the 1970s and the 1980s, even in the fiction by Morrison. According to Dubey, “[i]n black women's novels of the 1970s, folk culture is subject to a sharp scrutiny that exposes its often-damaging consequences for black women" (Black Women Novelists 7). She says, for example, that The Bluest Eye presents a northern community whose "mythical perception of nature" does not help its members to challenge racism and occasionally "[leads] to a dangerous fatalism" (Dubey, Black Women Novelists 44). For instance, Pecola's victimization is naturalized when Claudia speaks of her as a kind of flower that will not grow in that "soil," and as a fruit "that the land kills of its own volition" (The Bluest Eye, qtd. in Dubey, Black Women Novelists 44). Ascribing Pecola's tragedy to the environment in which she lives ("the land" and "soil"), allows the community to remain passive in the face of her suffering: "we acquiesce and say the victim had no right to live" (The Bluest Eye, qtd. in Dubey, ibid.). The novel seems in fact a criticism of such an attitude - it condemns violence and inaction made possible by a folk worldview. The Third Life of Grange Copeland, by Alice Walker, also puts across a mixed view of folklore. On the one hand, it abounds with Grange's edifying tales of conjurers and slaves verbally outwitting their masters, which emphasize the liberating potential of folklore as a shield against discrimination and oppression. On the other hand, the novel also rejects the black vernacular, one of the key components of folklore, which it describes as a "broken language" and a weapon with which men lash out at "Black ugly nigger bitch[es]" (139).

This does not mean that 1970s novels set forth a totally negative view of folklore; rather that their positioning on this subject was simply far more complex. Corregidora, for instance, celebrated the blues as a vehicle for black spirituality and hope. The blues and other forms of vernacular expression also provided BWR writers with a repository of formal and aesthetic tropes that enriched their writing on the level of both language and narrative structure. For example, the unique "spiral" or "circular" structuring of time that is found in the novels of the 1970s was indebted, according to Dubey, to folkloric, mythical and musical, frameworks. ${ }^{60}$ Sometimes, folk tales also shaped the storylines by creating escape routes for those characters who, like Son in Tar Baby or Milkman in Song of Solomon, did not fit into the imperfect real world.

By contrast, in the volkish tradition of the 1980s, myths and folktales began to signify the difference between essentialist ways of seeing the world imposed by cultural nationalist. In the heritage novels of the 1980s, the evocation of black folklore

60 According to Dubey, such novels as Meridian, The Bluest Eye, Eva's Man or Sula have "circular" structure because they "stage a bleak drama of history as overdetermined repetition" (136). 
goes beyond the "tokenism" of the 1970s. The writers embark on an ontological quest to validate an alternative black worldview and start to see folklore as an archive of eternal truths about black people, and themselves as custodians of that ancestral heritage. The black vernacular is no longer condemned for enabling a "monologic, derogatory construction of black women” (Dubey, Black Women Novelists 123) or for reinforcing the cultural marginalization of blacks: on the contrary, orality is seen as "fulfill[ing] the critical role of preserving cultural identity" (Braxton, "Ancestral Presence” 300). Folktales, songs, and spirituals are seen as receptacles of cultural essence, having "oral characteristics" that "speak to the realm in which the strongest and most empowering aspects of who we are collectively as a people is maintained" (John, Clear Word 2). That strong oral tradition and "black people's grace ... with language" (Watkins, "Talk with Toni Morrison” 48) are treated as the cornerstone of an essential "tribal literacy."

Like black male cultural nationalists of the 1960s and 70s, who "invested oral forms with special power to authorize a pure and untroubled collective voice in black literature" (Dubey, Black Women Novelists 139), so BWR writers of the 1980s used black folk idiom and oral motifs in an attempt to reproduce the voice of the people. The vernacular structuring of the narratives is evident in the use of the collaborative and performative "call and response pattern" (Mama Day, The Bluest Eye, Praisesong for the Widow), the collective first-person plural narrative voice ("we") (Mama Day); and omniscient and self-righteous narrators who clearly speak on behalf of a collectivity (Cliff). These narrative voices build what McClintock, in a different context, has called "a community of identity" of mostly female voices that reiterate collective memories of the ancestral past (Imperial Leather 317). These voices conjured parabolic stories of heroic black women who had been written out of the nationalist tradition (Cliff); forgotten legends (Tar Baby) and genealogies (Song of Solomon); and national names, songs and dances (Praisesong for the Widow). They produced what Gates called in The Signifying Monkey "talking books" which functioned as "authentic" products of culture and consciousness and sought to represent what Yuval-Davis called "the 'essence' of 'the nation' (Kulturnation)" (Gender and Nation 21).

It was a great achievement of the writers and feminist critics of the BWR that they developed this "conjure narratology" (Valerie Lee 137) and made it their own. Storytelling that was rooted in oral folk forms was increasingly presented as the business of kitchen poets and was compared to other female occupations like braiding hair, cooking and mothering. Black women's "talking books" reflected what Jacqueline Bryant called "mother's wit" and "mother's tongue" (20), and according to Barbara Smith, they came to constitute "an identifiable literary tradition"” ("Toward a Black Feminist Criticism" 416-7). Black feminist critics argued that this tradition was the legacy of black mothers who "arrogated to themselves and their daughters the power to create through language, to define themselves through the written word, to become witnesses to the special sensibility of black women" (Washington, "I Sign My Mother's Name” 144). It stemmed from black folk cosmology and lore, including such practices 
as rootworking, herbal medicine, conjure and midwifery, and was expressed through a discrete "specifically black female language" (Barbara Smith in McDowell, "New Directions for Black Feminist Criticism" 431). In Smith's opinion, the "innumerable commonalities' of language and theme that structure[d] ... [BWR] work" constituted a unitary woman-centered black aesthetic, distinct from the writings of both white women and black men ("Toward a Black Feminist Criticism" 21).

As McDowell has observed, the formation of this ethno-national canon, which sought to identify and reward those novels which best represented the feminist articulation of the imagined black community, was built at the expense of black men. ${ }^{61}$ Black feminist criticism actively endeavored to consolidate a certain vision of black female poetics and collectivity: McDowell, for instance, has noted that "feminist critics ... repudiated and subverted what they considered alien, male centered literary standards," replacing them with an oppositional "female aesthetic that reflected women's unique culture" ("The Changing Same” 50). She comments that this aesthetic was, however, "[s]imilar in spirit and methodology to the largely male-dominated black aesthetic movement," as it introduced a "no less rigid set of aesthetic orthodoxies" about what constitutes a successful synthesis of orality, myth and history in black writing (ibid. 19; 50). ${ }^{62}$ This depended on the exclusion of black male writers, such as Charles Johnson, David Bradley and Randall Kenan, who also occasionally conjured vernacular myths to "lie up the nation.” In their attempt to "[develop a] body of feminist political theory whose assumptions could be used in the study of black women's art” (Smith, “Toward a Black Feminist Criticism” 412), Smith and other black feminist critics had to disregard the fact that BWR writers were not the only ones to build their literary reputations on imaginative sojourns in the folk South.

Charles Johnson, David Bradley and Randall Kenan were not identified with the "the village novel" to the same extent as female writers. Morrison, for example, was adamant in her belief that what I call the volkish tradition was a hallmark of the BWR and that black women writers had different, quintessentially black, sensibilities

61 Similarly, Carby criticizes feminists, especially Barbara Smith, who constructed a tradition based on black female identity by creating a literary historiography of very divergent forms of black female cultural production. Carby argued that if there is such a tradition, it has not developed linearly (Reconstructing Womanhood).

62 "It is necessary to note," contended McDowell, that "ironically, in their earliest formulations, the objectives and practices of both the black aesthetic and feminist criticism often came dangerously close to insisting on a no less rigid set of aesthetic orthodoxies" ("The Changing Same" 50). She takes issue with Smith's essentialized and vague "critical jargon” (ibid. 8) which, as she aptly observes, was an example of "allowing ideology to inform critical analysis" (ibid. 8). McDowell points out that in Smith's discussion of the conjure aesthetics that was being presented as unique to the BWR, Smith did not provide any examples of the specifically black language that only BWR writers use. McDowell then asks: "is there a monolithic black female language? Do black female high school dropouts, welfare mothers, college graduates, and PhDs share a common language? Are there regional variations on this common language?" (ibid. 8). 
as compared with black men. According to Morrison, “[b]lack men don’t write very differently from white men," but there is an "enormous difference" in the narratives of black and white women. In her opinion, "[black] women probably do write off a different place. There is some difference in the ways they approach conflict, dominion and power" (qtd. in Edmondson, Making Men 100). In this way, she seems to intimate that BWR writing was genuinely black, unlike that of black men, since if black men's writing is indistinguishable from that of white men, then the writing of the BWR must presumably embody "authentic" black experience as captured in a recognizably black idiom. Furthermore, Morrison often expressed her belief in the existence of an authentic black novel that inscribes the authentic black voice. She certainly saw her own writing as a paragon of indigenous black fiction, as the following citation implies: "I try to incorporate, into that traditional genre of the novel, unorthodox novelistic characteristics - so it is in my view, Black, because it uses characteristics of Black art" (ibid.). Such claims have led Belinda Edmondson to conclude that "Morrison's logic seems to be grounded in the sort of essentialism that advocates that women are 'natural' bearers of culture, and therefore black women write with a sort of cultural intuitiveness that 'transcends' the adversarial (as I [Edmondson] think she would see it) phallocentric writings of black men, engaged as they are with racial politics" (ibid. 96). For Morrison, therefore, "blackness" is evidently a timeless cultural essence, an intuitive and "discursive feature" that relies on what Edmondson has called "an essential black female matrix" (ibid. 101).

The canonicity of BWR writers was constructed on this "essential black female matrix" and the urgency with which they strove to reconnect the modern African American "nation" with its pre-modern "ethnie." This matrix positioned black women writers as guardians of the African "spirit consciousness" and African "patterns of thought and the philosophical worldview" (John, Clear Word 158; 7), as encrypted in and expressed through the pastoral tradition. It presented contemporary society as lacking something desirable that was situated out of reach in the past, and it dramatized the tensions between tradition and modernity, country and city, the organic nature of indigenous folk tradition and grasping middle-class materialism. In short, the black female matrix adopted a politicized heritage rhetoric to counter both the history and the present reality of black disinheritance, and implied that this disinheritance could be reversed by a "sacramental repetition of folklore" (Gilroy, "Spiking the Argument" 186). It is important to emphasize that BWR heritage narratives never talked just about heritage; they dealt with the present as much as with the past. All purveyors of "mytho-poetic narratives" (Charles Johnson, Being and Race 103) have, as David Bradley has noted, "a hidden agenda," the aim of which is to "bend" men "with ritual": that is, to shape their sensibilities and worldview (Bradley, qtd. in John, Clear Word 158). Thus, BWR writers and critics were not passive recipients of inherited folk values and matrilineal traditions. On the contrary, they actively re-constructed heritage through creative writing and criticism in order to achieve preconceived social and political goals. 


\subsection{The "Essential Black Female Matrix" vs Goals of Black Feminism}

The volkish tradition made a significant contribution towards rehabilitating denigrated black cultures of the American South and provided black people with resources to construct everyday strategies of resistance. Toni Morrison called these resources "old values of the tribe" ("Rootedness" 341) and claimed that her novels are like sermons, whose purpose is to heal, to effect change, and to "[unify] the tribe" (Braxton, "Ancestral Presence” 300). Written in black idiom and shaped by black cultural archetypes, Morrison's narratives used folk material to create a sense of a stable and immutable identity, something that black people could, indeed, "fall back on." Her evocation of folk culture tapped into a resonant archive of popular memory and the iconography of historical ordeals to provide the historical dimension necessary for national/tribal invention, a forum for the collective reliving of the past, and a rallying point for the future. Likewise, the narratives of other BWR women, such as Marshall, Naylor and Cliff, to name just a few, built bridges between the linear historical time of progress and the pastoral, cyclical time of rural nostalgia, in order to make it possible for urbanized, middle-class African Americans to face the political, social and economic challenges of racist America with greater confidence. These narratives secured for BWR writers a space in the African American literary canon and made the BWR "a vivid new fact of national life" (Hortense Spillers, qtd. in McDowell, "The Changing Same" xiii).

On the other hand, however, the writing of the BWR suggests that when artists and critics believe that they are not inventors of politically and culturally useful myths but "mediums" speaking to their readers directly from the "miasma of the past," folklore can become a dangerous trap. Writing that treats heritage as a revered cultural bequest can produce what Edouard Glissant called "petrified" culture (Caribbean Discourse 210), or what Arjun Appadurai called "metonymic freezing," where folk culture is presented as a static, rural, idealized past, against which all aspects of the present are measured. Metonymic freezing is Appadurai's synonym for essentialising representational strategies, whereby "one feature of a group - attached to the group, so to speak - may come to represent the group as its quintessence" ("Putting Hierarchy in Its Place” 36). He sees assumptions about black people's lingering "tribal” sensibility, supernatural ways of knowing, traditional constructions of black femininity and matriliny, and the universal dexterity of black people (particularly women) with language as "metonymic prisons" for a people who are endowed with certain prescribed racial characteristics (ibid.). Metonymic freezing also affects entire communities and places, such as the extended Caribbean. Speaking about Martinique, Glissant often described the poignancy of being "from a community that has been reduced to its folklore; to whom all productions except folkloric are forbidden" (Caribbean Discourse 151). Glissant warned against the "trap of folklore" as a special kind of escapism that offers a "neutralized, stagnant" form of pseudo-history and "contributes to a collec- 
tive drift into oblivion” (ibid. 210). "Literature,” he argued, should not ““function' as a simple return to oral sources of folklore" (ibid. 151).

The fetishistic view of culture as a "stock of particularisms" (Fanon, qtd. in McDowell, "The Changing Same" 114) and of cultural identity as a "metonymic prison" has had unpleasant consequences for black women in particular. Nationalist rhetoric traditionally presents women, on the one hand, "as the atavistic and authentic body of national tradition (inert, backward-looking and natural), embodying nationalism's conservative principle of continuity" (McClintock, Imperial Leather 359); and men, on the other, as agents of progress, modernization, and urbanization. BWR heritage fiction was based on the same well-rehearsed, reductionist and essentialist dichotomy, in which, as Trudier Harris among others has argued, men personify nationalism's principle of revolutionary change and women incarnate continuity and heritage. While men's writing ranked modernity and progress above nature, and consequently valued men above women, BWR writers reversed that hierarchy and gave preference to the green matriarchal world. In this way, BWR novels retained and even reinforced the masculine tradition that saw black women as traditional "pots of culture" 63 linked to nature (Stratton, Contemporary African Culture 39). The volkish tradition contributed to the perpetuation of the myth of "the generic black woman," to paraphrase Elizabeth Spelman's expression (Inessential Woman ix), be it in the form of a conjure woman, a community mother or a doting daughter. This understanding of female agency not only reiterated standard gender divisions and exclusions; within the domain of black feminist thought, it actually functioned in much the same way as the notion of "generic" man did in Western philosophy (Spelman, Inessential Woman ix).

Heritage studies has been said to be blind to questions of gender (Smith, "Heritage, Gender and Identity” 159), but BWR novels show the myriad ways in which gender does, in fact, inflect the discourses of heritage. In BWR volkish fiction women are associated with tradition, spirituality and domesticity, and they are made to inhabit the rural settings. Mama Day, Pilate, the Carriacou women (Praisesong for the Widow), Miss Mattie and the women of Eloe (Tar Baby) all draw their strength from the perfect rapport they have with nature and the wisdom they derive from the lore of the folk. As

63 In her chapter "The Mother Africa Trope," Stratton argues that the trope has taken two distinct forms, one of which, I think, also rather accurately describes the Afrocentric womanist prose of the BWR in the 1980s. Stratton suggests that in the fiction of African nationalist men, women were represented either as the "pot of culture" or a "sweep of history" (39). In the first version of the trope, the African woman is identified with tradition, and with timeless values impervious to historic change. She says that this form of the Mother Africa trope "analogizes woman to a bygone culture which is usually conceptualized as immutable, rendering the female figure static, conservative, and ahistorical" (Contemporary African Literature 50). The woman, reduced to a nurturing mother, then becomes, in effect, "a symbol of essence” (Bryan, qtd. in Stratton 45), or, as Stratton herself has aptly put it, she is an "attractive packaging" for heritage (ibid. 52). 
Yuval-Davis has pointed out, much of the explanation for women's oppression can be found in the divergent placement of men and women with respect to the oppositions between civilization and nature and public and private domains. She notes that "[a]s nationalism and nations have usually been discussed as a part of the public political sphere, the exclusion of women from that arena has affected their exclusion from that discourse as well" (Gender and Nation 12-13). To a certain degree, BWR writers can be said to have remolded this stereotypical configuration that equates women as "inert, backward-looking and natural" to a "body of national tradition" (McClintock, "No Longer in a Future Heaven”" 92). By contrast with masculine nationalist discourse, which usually gave men forward-thrusting, potent and historic roles, BWR narratives did not generally value male protagonists (with the exception perhaps of Morrison's Son and Milkman Dead). They refocused on representing the everyday heroism of blood-and-other mothers and the daughters of the nation, cast in the metonymic rather than metaphoric roles of national actors and leaders.

On the other hand, however, as Maxine Lavon Montgomery has argued, while BWR heritage novels such as Mama Day did "[reveal] women's expanding sphere of influence," the model of female empowerment that they offered was still limited to the domestic and folkloric spheres ("Good House Keeping” 64). Although women's domestic work no longer had the pejorative connotations of female servitude and entrapment in menial jobs, it was instead presented as a means of creatively fashioning the community and the self. These narratives suggested that conjuring, healing, "matriarchal mythmaking” (Andrews, "Black Sisterhood" 287) and other traditional female occupations, such as nurturing, cooking and weaving, can be liberating for women if performed for their own families and rooted in black folklore. Seen from this perspective, the domestic sphere was no longer seen as "a place of bondage and subjugation" for women but a place "of rebirth and renewal" that "takes on spiritual dimensions, allowing black women to transcend imposed notions of female place" (Montgomery, “Good House Keeping” 64). Nonetheless, as Andrews has noted, none of the novels imagines black female self-fashioning and empowerment outside the kumbla of "female folk tradition and nature" ("Black Sisterhood" 287).

This approach to black female subjectivity obscured the heterogeneity of black women's experiences and attempted to maintain gender conformity within black communities. It aimed to forge "affective affiliations" among women even where "such affiliations [were] far from automatic” (McDowell, "The Changing Same” 20). The ideas of female solidarity, bonding and sisterhood, which were championed by womanism and BWR heritage writing, were often used by writers and critics to educate, socialize and "police" those "sisters" who did not want to conform. In the words of bell hooks, "the black women who speak the most about love and sisterhood" were the ones who were most "deeply attached to essentialist notions of black female identity" ("Revolutionary Black Women” 221). These black feminists, according to hooks, used creative writing and literary criticism to censure all internal dissent, especially with regard to women's roles as the core of family, culture and community: 
the struggle by black female characters for subjectivity, though forged in radical resistance to the status quo, (opposition to racist oppression, less frequently to class and gender) usually takes the form of black women breaking free from boundaries imposed by others only to practice their newfound "freedom" by setting limits and boundaries for themselves. Hence though black women may make themselves "subject" they do not become radical subjects. Often they simply conform to existing norms, even ones they once resisted. (ibid.)

By "conform[ing] to existing norms," hooks means that "the heroines settle down into conventional gender roles" (ibid. 222) ${ }^{64}$ She argues that in many women's novels, the pursuit of self and identity is seen as a narcissistic act, a form of wildness that backfires on women who "go against the grain." These women undergo nervous breakdowns and need the help of elders in order to come to their senses (such as Velma in The Salt Eaters, Avey in Praisesong for the Widow, and Merle in The Chosen Place, The Timeless People, for example) or suffer from acute inauthenticity neurosis (as does Jadine in Tar Baby, Meridian, Clare in Abeng and No Telephone to Heaven).

As Yuval-Davis has noted, Kulturnation, ideation that is focused on the essence of national identity, “tends to have little tolerance of 'non-organic' diversity" (Gender \& Nation 21). Even though the myth-symbol complex is "a rich resource, usually full of internal contradictions" rather than "a fixed and homogenous body of tradition and custom" (ibid. 43), it is usually the case that at any given time only one vision of cultural authenticity and one accepted interpretation of heritage prevails. Ethnic communities and nations privilege unity over difference; they seek to eliminate schism, friction and dissent, and to define and defend at all costs what would otherwise just be "open and indeterminate frontiers" (Chantal Mouffe, qtd. in Sharp, "Gendering Nationhood" 104). This intolerance for diversity explains the widespread exclusion and condemnation in writing of the BWR of female characters such as Jadine or Avey, and also writers such as Kincaid, who have partially, temporarily or completely "lost their ancient properties" (Toni Morrison, Tar Baby 305). LeClair has noted that Morrison seems to be the most uncompromising and harsh judge of models of black womanhood that go against the grain ("The Language Must Not Sweat" 121). In her drive towards what Chantal Mouffe called "totalizing effects" (qtd. in Sharp, "Gendering Nationhood" 104), ${ }^{65}$ Morrison refuses black women emancipation, self-identity and fulfillment outside of the wider struggle for black liberation and nationalist ideas con-

64 Thus, according to hooks, Ruth, in The Third Life of Grange Copeland, is kept in place by strong male patriarchs; Meridian "never developed a social and political success"; Celie, in The Color Purple, is "described within the context of family and domestic relations ... The primary change is that these relations are no longer abusive"; and finally, Sula "is not self-actualized enough to stay alive" ("Revolutionary Black Women" 224; 222-3; 222).

65 As Chantal Mouffe stated, while plurality inevitably exists within nations and communities, "[t]his plurality does not involve the coexistence, one by one, of a plurality of subject positions but rather the constant subversion and overdetermination of one by the others, which makes possible the generation of 'totalizing effects' within a field characterized by open and indeterminate frontiers" (Chantal Mouffe, qtd. in Sharp, "Gendering Nationhood" 104). 
cerning traditional codes of practice and belief. She rejects, in her 1980s novels, the very possibility of the existence of a plurality of subject positions for women within the "tribe." She often speaks of "her people" or "her tribe" and claims that peasant literature helps her to get in touch "with all sorts of people." The problem with this, as Lars Eckstein has aptly remarked, is that Morrison has also marginalized all sorts of people. It created a privileged in-group of blacks who believe in "old values" on the one hand, and an underprivileged out-group of those black people who adopted "new urban values" ("Re-Membering" 232-3). Other novels that made up in the 1980s the volkish tradition also represented women's desire for radical emancipation as a traitorous and despicable act. 